\title{
POLA MUSIM DI INDONESIA TAHUN 2002 SAMPAI 2016 BERDASARKAN EQUIVALENT WATER HEIGHT (EWH)
}

\author{
Safri Yanti Rahayu ${ }^{1}$, Ira Mutiara Anjasmara² \\ 1,2Departemen Teknik Geomatika, FTSLK-ITS, Kampus ITS Sukolilo, Surabaya, 60111, Indonesia \\ e-mail: 2ira@geodesy.its.ac.id
}

\begin{abstract}
Abstrak
Musim adalah cuaca pada rentang waktu tertentu yang paling jelas terlihat. Bersadarkan letak geografisnya, variasi musim di Indonesia yang paling mencolok adalah pada curah hujan. Perubahan musim disebut juga dengan perubahan cuaca yang dihasilkan oleh interaksi air permukaan seperti siklus air. Hal ini menunjukkan bahwa variasi cuaca berkaitan dengan perubahan massa air di bumi. Ketersediaan air dapat dilihat dari variasi Equivalent Water Height (EWH) yang didapatkan dari data satelit gayaberat Gravity Recovery and Climate Experiment (GRACE) kemudian digunakan Data satelit TRMM (Tropical Rainfall Measuring Mission) dapat digunakan untuk mengamati curah hujan serta sebagai pendukung data dari satelit GRACE. Dari hasil pengolahan data satelit gayaberat GRACE, nilai EWH terbesar adalah $27.298 \mathrm{~cm}$ pada bulan Januari 2015 dan Nilai EWH terkecil $-29.816 \mathrm{~cm}$ adalah pada bulan Juni 2004 terjadi di Pulau Sumatera. Sepanjang tahun 2002 sampai 2016 Perubahan pola musim terjadi pada tahun 2010 dan 2015 yang masing-masing disebabkan oleh terjadinya perubahan curah hujan secara ekstrim dan oleh terjadinya peristiwa El Nino.
\end{abstract}

Kata Kunci: GRACE, koefisien spherical harmonic, Equivalent Water Height (EWH), TRMM

\begin{abstract}
Season is the weather that is clearly visible at certain timescales. Based on its geographical location, the most striking seasonal variation in Indonesia is rainfall. Seasonal changes are also called weather changes that result from surface water interactions such as the water cycle. This shows that weather variations are related to changes in water mass on earth. Water availability can be seen from the Equivalent Water Height (EWH) variations obtained from gravity satellite data Gravity Recovery and Climate Experiment (GRACE) then the used of TRMM (Tropical Rainfall Measuring Mission) satellite data can be used to observe rainfall as well as supporting data for GRACE satellites. From the results of GRACE gravity satellite data processing, the largest EWH value was $27.298 \mathrm{~cm}$ in January 2015 and the smallest EWH value of $-29.816 \mathrm{~cm}$ was in June 2004 on Sumatra Island. During the years 2002 to 2016 Changes in seasonal patterns occurred in 2010 and 2015, each of which was caused by extreme changes in rainfall and by the occurrence of El Nino events.
\end{abstract}

Keywords: GRACE, spherical harmonic coefficient, Equivalent Water Height (EWH), TRMM 


\section{PENDAHULUAN}

Musim adalah keadaan rata-rata cuaca pada suatu wilayah dalam rentang waktu yang banyak. Musim di Indonesia paling sering ditunjukkan oleh banyaknya curah hujan. Sehingga musim di Indonesia dapat dibedakan menjadi musim hujan dan musim kemarau (Aldrian, 2014).

Indonesia merupakan negara yang berada pada kawasan katulistiwa. Hal ini mengindikasikan panjang siang dan malam pada wilayah Indonesia hampir sama serta intensitas cahaya matahari yang diterima pada siang dan malam hari sangat kontras. Hal ini akan menyebabkan sifat cuaca pada siang dan malam hari berbeda. Proses ini terjadi secara terus-menerus sehingga Indonesia memiliki variasi cuaca yang sangat jelas dan perubahan yang terjadi pada variasi cuaca tersebut dapat diamati dengan jelas (Wirjohamidjoyo \& Swarinoto, 2010).

Berdasarkan hasil penelitian yang dilakukan oleh Aldirian, data curah hujan tahunan mengindikasikan penurunan curah hujan di hampir seluruh 63 stasiun pengamatan BMKG. Perubahan curah hujan ini sangat erat kaitannya dengan perubahan musim Pada keadaan normal, pola musim menunjukkan curahan hujan sekitar $80 \%$ pada musim hujan mengalami peningkatan (Aldrian, 2014).

Data Satelit GRACE (Gravity Recovery and Climate Experiment) untuk pemantauan gayaberat dapat digunakan untuk mengamati variasi massa air dalam bentuk Equivalent Water Height (EWH) (Ahmed et al., 2011; Wahr, Molenaar, Bryan, 1998). Data satelit TRMM (Tropical Rainfall Measuring Mission) dapat digunakan untuk mengamati curah hujan serta sebagai pendukung data dari satelit GRACE.

EWH adalah perbedaan solusi bulanan (seperti gangguan potensial, undulasi geoid), yang disebabkan oleh redistribusi massa dalam pengukuran gayaberat, ada efek pengukuran (seperti tekanan udara dan pasang surut) dapat dimodelkan dan dihilangkan dari data pengukuran. Perbedaan sisa yang dihasilkan setelah menghilangkan efek tersebut disebabkan oleh redistribusi massa air (ICGEM, 2017).

\section{METODOLOGI PENELITIAN}

\section{Lokasi Penelitian}

Lokasi yang dijadikan studi dalam penelitian ini adalah wilayah Indonesia Indonesia dengan posisi geografis $95^{\circ}$ BT - $141^{\circ}$ BT dan $6^{\circ} \mathrm{LU}-11^{\circ} \mathrm{LS}$. Peta lokasi penelitian dapat dilihat pada Gambar 1.

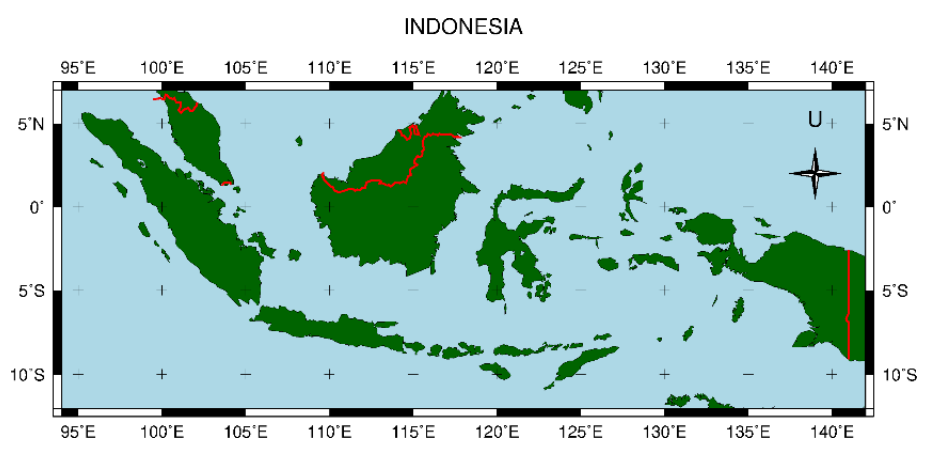

Gambar 1. Lokasi Penelitian

\section{Data dan Tahapan Pengolahan Data}

Data yang digunakan dalam melakukan penelitian ini adalah sebagai berikut.

a. Data satelit GRACE Level 2 dalam bentuk spherical harmonic yang dapat diunduh di (ftp://podaac.jpl. nasa.gov/allData/grace/L2/CSR/RL06/) dari tahun 2002 hingga tahun 2016

b. Koefisien C20 spherical harmonic yang dapat diunduh di ftp://ftp.csr.utexas.edu/pub/slr/degre e_2/

c. Koefisien 1 derajat spherical harmonic yang dapat diunduh di ftp://podaac.jpl.nasa.gov/allData/tell us/L2/degree_1/

d. Data koreksi Glacial Isostatic Adjustment (GIA) yang dapat diunduh di ftp://podaac-ftp.jpl.nasa. gov/allData/tellus/L3/pgr/GIA_n100_mass_0km.txt

e.Data TRMM 3B43 yang dapat diunduh di http://mirador.gsfc.nasa.gov dengan rentang waktu dari tahun 2002 hingga tahun 2016

Adapun tahapan pengolahan data yang dilakukan dalam penelitian ini adalah sebagai berikut.

a. Pengolahan data GRACE level 2

Ekstraksi Equivalent Water Height (EWH) dari data spherical harmonic menggunakan GRACE_Matlab_ Toolbox. Gambar 2 menunjukkan GUI GRACE_ Matlab_Toolbox yang digunakan untuk pengolahan data. 


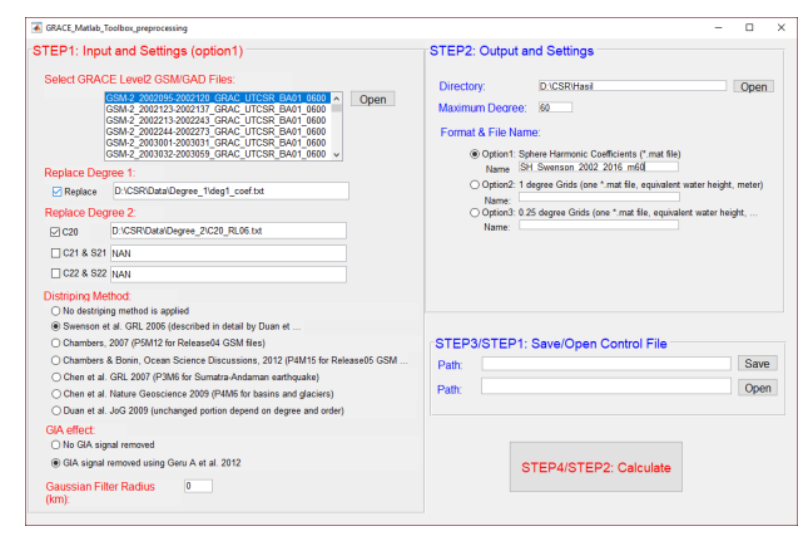

Gambar 2. GUI GRACE_Matlab_Toolbox

\section{b.Pengolahan Data TRMM 3B43}

Ekstraksi nilai precipitation (PCP) menggunakan perangkat lunak Generic Mapping Tools (GMT)

c. Uji Korelasi

Uji korelasi dilakukan menggunakan perangkat lunak minitab. Uji korelasi ini digunakan untuk mengetahui hubungan antar EWH dari mascon dengan EWH hasil pengolahan GRACE level 2. Kedua data dinyatakan memiliki korelasi apabila nilai korelasinya berada antara -1 dan 1 .

\section{d. Time series}

Plotting grafik time series Equivalent Water Height (EWH) dilakukan menggunakan software minitab.

e. Tren

Untuk mengetahui nilai tren Equivalent Water Height (EWH) dapat dilakukan dengan menggunakan regrasi linear.

f. Analisis Pola Musim

Analisis digunakan untuk wilayah yang memiliki slope tren tinggi (mengalami kenaikan atau penurunan tren yang signifikan). Analisis perubahan musim dilakukan dengan cara menyocokkan kondisi musim hujan Indonesia rata-rata. Kemudian divalidasi dengan data curah hujan dari satelit TRMM.

\section{HASIL DAN ANALISIS}

\section{Hasil Pembagian wilayah Indonesia per $10^{\circ}$}

Koordinat titik tengah pembagian wilayah Indonesia per $10^{\circ}$ sehingga menjadi 18 bagian ditunjukkan pada tabel 1 dan divisualisasikan pada Gambar 3.
Tabel 1. Pembagian wilayah Indonesia per $10^{\circ}$

\begin{tabular}{ccc}
\hline Bagian & \multicolumn{2}{c}{ Koordinat titik bagian } \\
\cline { 2 - 3 } & Bujur & Lintang \\
\hline 1 & 93.25 & 7.25 \\
2 & 103.25 & 7.25 \\
3 & 113.25 & 7.25 \\
4 & 123.25 & 7.25 \\
5 & 133.25 & 7.25 \\
6 & 143.25 & 7.25 \\
7 & 93.25 & -2.75 \\
8 & 103.25 & -2.75 \\
9 & 113.25 & -2.75 \\
10 & 123.25 & -2.75 \\
11 & 133.25 & -2.75 \\
12 & 143.25 & -2.75 \\
13 & 93.25 & -12.75 \\
14 & 103.25 & -12.75 \\
15 & 113.25 & -12.75 \\
16 & 123.25 & -12.75 \\
17 & 133.25 & -12.75 \\
18 & 143.25 & -12.75 \\
\hline & &
\end{tabular}

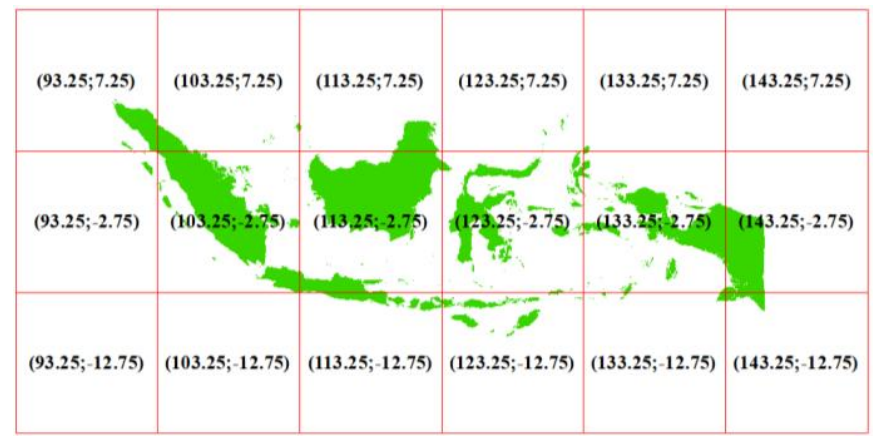

Gambar 3 visualisasi pembagian wilayah Indonesia per $10^{\circ}$

\section{Equivalent Water Height (EWH) dari GRACE level 2}

Ekstraksi Equivalent Water Height (EWH) dari data spherical harmonic dilakukan menggunakan GRACE_Matlab_Toolbox. Hasil yang didapatkan dari pengolahan data tersebut adalah nilai EWH dari tahun 2002 hingga 2016 dalam satu file yang memiliki format grid dengan ukuran $180 \times 360 \times 117$ sehingga harus diekstrak menjadi nilai EWH per bulan sepanjang tahun 2002 sampai 2016. Ekstraksi nilai EWH perbulan dilakukan dengan menggunakan software MATLAB. Gambar 4 berikut adalah salah satu contoh hasil plotting nilai EWH dari data satelit gayaberat GRACE level 2. 


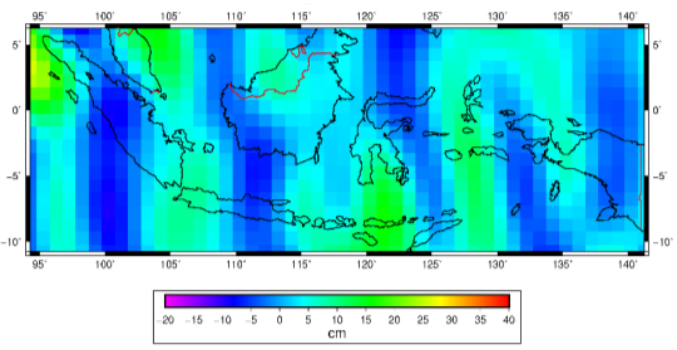

Gambar 4 EWH GRACE level 2 bulan April 2002

\section{Nilai precipitation (PCP)}

Nilai presipitasi diekstraksi dari data TRMM 3B43 yang telah diunduh. Untuk melihat nilai presipitasi secara spasial maka dilakukan plotting nilai presipitasi menggunakan software GMT. Gambar 5 menunjukkan hasil plotiing nilai presipitasi pada bulan April 2002.

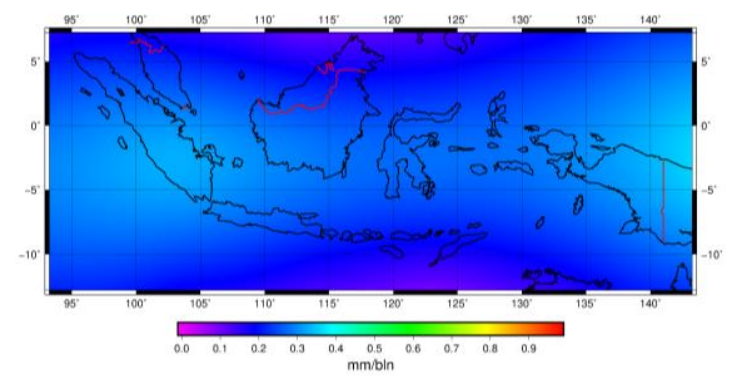

Gambar 5 Nilai presipitasi Indonesia bulan April 2002

\section{Nilai korelasi EWH Mascon dan EWH GRACE level 2}

Data yang digunakan sebagai referensi adalah data Mascon. Karena data Mascon merupakan data yang telah dikoreksi dari berbagai bias dan noise (NASA, 2017). Nilai Korelasi EWH Mascon dan EWH GRACE level 2 ditunjukkan pada Tabel 2.

Tabel 2. Nilai Korelasi EWH GRACE level 2 dan Presipitasi

\begin{tabular}{|c|c|c|c|c|}
\hline \multirow{2}{*}{ Wilayah } & \multicolumn{2}{|c|}{$\begin{array}{c}\text { Koordinat Titik } \\
\text { Tengah }\end{array}$} & \multirow{2}{*}{$\begin{array}{c}\text { Nilai } \\
\text { Korelasi }\end{array}$} & \multirow{2}{*}{$\begin{array}{c}\text { Tingkat } \\
\text { hubungan }\end{array}$} \\
\hline & Bujur $\left({ }^{\circ}\right)$ & Lintang $\left({ }^{\circ}\right)$ & & \\
\hline 1 & 93.25 & 7.25 & 0.17 & $\begin{array}{l}\text { Sangat } \\
\text { Lemah }\end{array}$ \\
\hline 2 & 103.25 & 7.25 & 0.45 & Cukup Kuat \\
\hline 3 & 113.25 & 7.25 & 0.44 & Cukup Kuat \\
\hline 4 & 123.25 & 7.25 & 0.39 & Lemah \\
\hline 5 & 133.25 & 7.25 & 0.47 & Cukup Kuat \\
\hline 6 & 143.25 & 7.25 & 0.31 & Lemah \\
\hline 7 & 93.25 & -2.75 & 0.42 & Cukup Kuat \\
\hline 8 & 103.25 & -2.75 & 0.51 & Cukup Kuat \\
\hline 9 & 113.25 & -2.75 & 0.25 & Lemah \\
\hline 10 & 123.25 & -2.75 & 0.27 & Lemah \\
\hline
\end{tabular}

\begin{tabular}{|c|c|c|c|c|}
\hline 11 & 133.25 & -2.75 & 0.27 & Lemah \\
\hline 12 & 143.25 & -2.75 & -0.19 & $\begin{array}{l}\text { Sangat } \\
\text { Lemah }\end{array}$ \\
\hline 13 & 93.25 & -12.75 & -0.37 & Lemah \\
\hline 14 & 103.25 & -12.75 & -0.20 & Lemah \\
\hline 15 & 113.25 & -12.75 & -0.22 & Lemah \\
\hline 16 & 123.25 & -12.75 & 0.59 & Cukup Kuat \\
\hline 17 & 133.25 & -12.75 & 0.67 & Kuat \\
\hline 18 & 143.25 & -12.75 & 0.75 & Kuat \\
\hline
\end{tabular}

Dari Tabel 2 dapat dilihat bahwa hubungan nilai EWH yang telah diperoleh dari pengolahan data GRACE level 2 dan nilai presipitasi yang telah diekstrak dari data satelit TRMM tidak ada yang menunjukkan hubungan sangat kuat (Aditya, 2016). Ada 2 wilayah yang menunjukkan hubungan kuat, yaitu wilayah 17 dan 18 yang meliputi sebagian kecil Irian Jaya sebelah selatan. 6 wilayah yang memiliki hubungan cukup kuat yang meliputi wilayah 2,3, 5, 7, 8 dan 16. Sebagian wilayah ini adalah bagian utara pulau Kalimantan dan Pulau Sumatera, Sumatera bagian tengah, serta kepulauan Bali dan Lombok. Ada 8 wilayah yang memiliki hubungan lemah yaitu wilayah 4,6,9,10,11,13,14, dan 15 yang meliputi Pulau Sulawesi, sebagian besar Pulau Kalimantan dan Pulau Irian Jaya. Wilayah 1 menunjukkan hubungan yang sangat lemah. Hal ini dapat memperkuat dugaan bahwa fluktuasi nilai EWH yang signifikan pada wilayah ini disebabkan oleh redistribusi massa yang terjadi akibat bencana alam silam. Ada 4 wilayah yang tidak memiliki hubungan sama sekali tidak ada, yaitu selatan Pulau Sumatera.

\section{Time Series EWH GRACE level 2}

Deret waktu (time series) nilai EWH diplot berdasarkan pembagian wilayah Indonesia (per $10^{\circ}$ ). Gambar 6 berikut ini merupakan contoh time series EWH dari data GRACE level 2 pada wilayah 1.

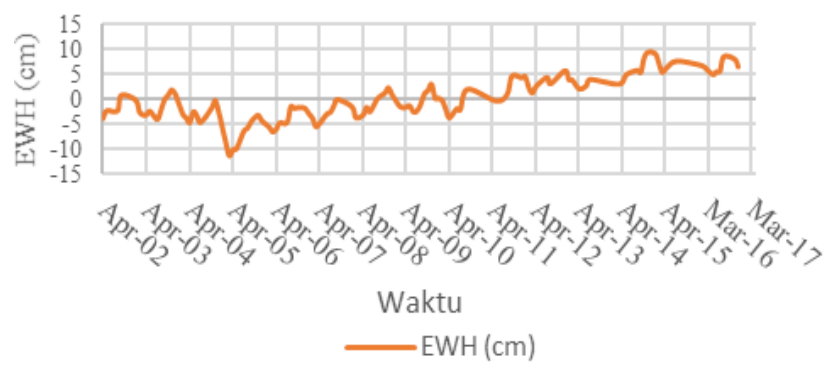

Gambar 6 Time Series EWH GRACE level $2(93,25 ; 7,25)$ 


\section{Trend EWH GRACE level 2}

Trend nilai EWH diplot berdasarkan pembagian wilayah Indonesia (per $10^{\circ}$ ). Plottingan Trend dilakukan menggunakan perangkat lunak GMT. Tabel 4.3 berisi persamaaan linier tren tiap wilayah yang terditri dari unsur $y$ yang merupakan nilai EWH dan $x$ yang menunjukkan waktu.

Tabel 3. Tren Linier Nilai EWH

\begin{tabular}{cc}
\hline Wilayah & Persamaan \\
\hline 1 & $y=-5867+0.09942 \mathrm{x}$ \\
2 & $y=4.611-0.0783 \mathrm{x}$ \\
3 & $y=-0.521+0.0054 \mathrm{x}$ \\
4 & $y=-1.500+0.02517 \mathrm{x}$ \\
5 & $y=0.536-0.00943 \mathrm{x}$ \\
6 & $y=-1.185+0.01999 \mathrm{x}$ \\
7 & $y=-0.184+0.00289 \mathrm{x}$ \\
8 & $y=-0.981+0.01689 \mathrm{x}$ \\
9 & $y=1.325-0.02235 \mathrm{x}$ \\
10 & $y=-1.443+0.02444 \mathrm{x}$ \\
11 & $y=-0.617+0.01028 \mathrm{x}$ \\
12 & $y=-0.838+0.0142 \mathrm{x}$ \\
13 & $y=0.031-0.00080 \mathrm{x}$ \\
14 & $y=-0.767+0.01295 \mathrm{x}$ \\
15 & $y=0.701-0.01192 \mathrm{x}$ \\
16 & $y=-0.385+0.00652 \mathrm{x}$ \\
17 & $y=-0.84+0.0153 \mathrm{x}$ \\
18 & $y=-0.787+0.0140 \mathrm{x}$ \\
\hline
\end{tabular}

Dari Tabel 4.3 dapat diambil kesimpulan bahwa wilayah yang memiliki tren yang signifikan (baik naik maupun turun) berada pada wilayah $1,2,4,6,8,9,10$, 11, 14 dan 15. Pada wilayah inilah dilakukan analisis terhadap perubahan musim.

Terjadinya pergeseran musim pada tahun 2010 diakibatkan oleh adanya perubahan iklim yang nyata pada tahun tersebut. Kemarau basah sepanjangtahun 2010 yang pada akhirnya tidak terjadinya kemarau pada akhir tahun (Aldrian, 2014).

Dari data tren di semua wilayah menunjukkan bahwa selain pada tahun 2010, terjadi pula perubahan pola musim sekitar pada 2013. Hal ini dapat diakibatkan oleh terjadinya pemanasan global yang sangat signifikan pada tahun 2014 dengan kenaikan suhu sebesar $0.65^{\circ} \mathrm{C}$ (Hairiah, et al., 2016) yang ditunjukkan pada penurunan intensitas curah hujan pada bulan maret 2014 yang meningkat. Menurut BMKG (BMKG, 2015). Sejak akhir tahun 2014 kondisi di Ekuator Pasifik Tengah (Nino 3.4) berada pada kondisi yang cenderung hangat, kondisi ini terus berlanjut hingga Juli 2015. Pada akhir Juli 2015 indeks Nino 3.4 sudah berada pada kondisi El Nino Moderate Hal ini yang kemudian menyebabkan Musim Hujan 2015 di Wilayah Indonesia mengalami kemunduran sampai beberapa dasarian dari normalnya (BMKG, 2015).

\section{KESIMPULAN}

Kesimpulan yang dapat diambil dari penelitian ini adalah sebagai berikut.

1. Nilai EWH terbesar adalah $27.298 \mathrm{~cm}$ pada bulan Januari 2015 dengan posisi $\left(3.25^{\circ} ; 94.25^{\circ}\right)$ tepatnya pada wilayah bagian kedelapan yaitu di Pulau Sumatera.

2. Nilai EWH terkecil $-29,816 \mathrm{~cm}$ adalah pada bulan Juni 2004 dengan posisi $\left(1.25^{\circ} ; 95.25^{\circ}\right)$ tepatnya pada wilayah bagian kedelapan yaitu di Pulau Sumatera.

3. Kecepatan perubahan EWH maksimum terjadi pada wilayah dengan posisi $\left(-0.75^{\circ} ; 98.25^{\circ}\right)$ yaitu di laut selatan Pulau Sumatera dengan kecepatan 21.71 $\mathrm{mm} /$ tahun

4. Kecepatan perubahan EWH maksimum terjadi pada wilayah dengan posisi $\left(-10.5^{\circ} ; 133.25^{\circ}\right)$ yaitu di laut selatan Pulau Irian Jaya dengan kecepatan -26.36 $\mathrm{mm} /$ tahun

5. Perubahan pola musiman yang ditunjukkan oleh data satelit gayaberat GRACE ialah terjadinya pergeseran musim pada tahun 2010 dan tahun 2015.

6. Perubahan pola musim pada tahun 2010 yang ditunjukkan oleh pola musiman EWH disebabkan oleh terjadinya perubahan curah hujan secara ekstrim.

7. Perubahan musim pada tahun 2015 yang ditunjukkan oleh pola musiman EWH disebabkan oleh terjadinya peristiwa El Nino.

\section{UCAPAN TERIMA KASIH}

Penulis S.Y.R mengucapkan terima kasih kepada Ibu Ira Mutiara Anjasmara, ST., M. Phil., Ph.D., selaku dosen pembimbing yang telah memberikan bimbingan dalam melakakukan penelitian ini.

\section{DAFTAR PUSTAKA}

E. Aldrian, "Pemahaman Dinamika Iklim Di Negara Kepulauan Indonesia Sebagai Modalitas Ketahanan Bangsa," pp. 7-8, 2014.

S. Wirjohamidjoyo and Y. Swarinoto, Iklim Kawasan Indonesia (Dari Aspek Dinamik - Sinoptik). Jakarta: Badan Meteorologi Klimatologi dan Geofisika, 2010.

M. Ahmed et al., "Use of GRACE data to monitor climate change-induced variations in water storage 
availability in the African continent," 2011. [Online]. Available:

https://www.researchgate.net/publication/2601640 54_Use_of_GRACE_data_to_monitor_climate_chang e-

induced_variations_in_water_storage_availability_in _the_African_continent/related. [Accessed: 29-Dec2018].

J. Wahr, M. Molenaar, and F. Bryan, "Time variability of the Earth's gravity field: Hydrological and oceanic effects and their possible detection using GRACE," vol. 103, pp. 205-229, 1998.

ICGEM, "ICGEM Service Frequently Asked Questions (FAQs)," p. 21, 2017.

NASA, “Monthly Mass Grids - Global mascons (RL06)." 2017.

B. W. Aditya, "Analisa Pemodelan Pola Aliran Hidrologi Menggunakan Satelit Gaya Berat Grace Untuk Wilayah Kepulauan (Studi Kasus: Kepulauan Indonesia Tahun 2005-2015)," Institut Teknologi Sepuluh Nopember, 2016.

K. Hairiah, S. Rahayu, D. Suprayogo, and C. Prayogo, Perubahan iklim: Sebab dan Dampaknya Terhadap Kehidupan. Malang,: World Agroforestry Centre (ICRAF), 2016.

BMKG, “Prakiraan Musim Hujan 2015 - 2016 di Indonesia," pp.1-93,2015.

\section{LAMPIRAN}

\section{EWH dan presipitasi bulanan}

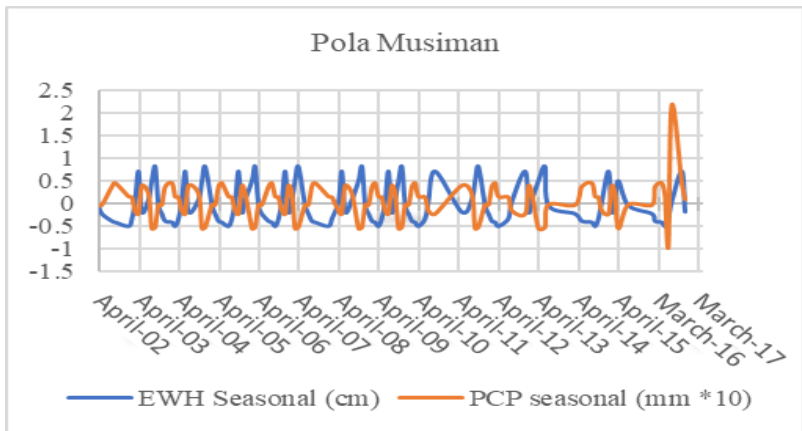

Analisis musim wilayah 1

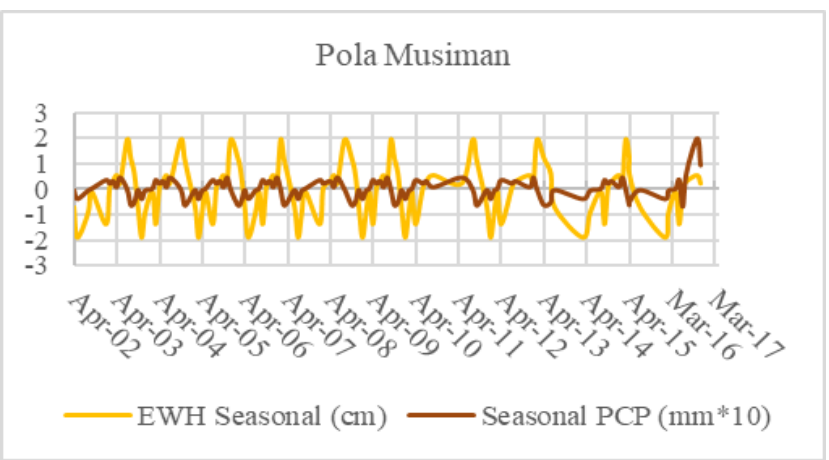

Analisis musim wilayah 2

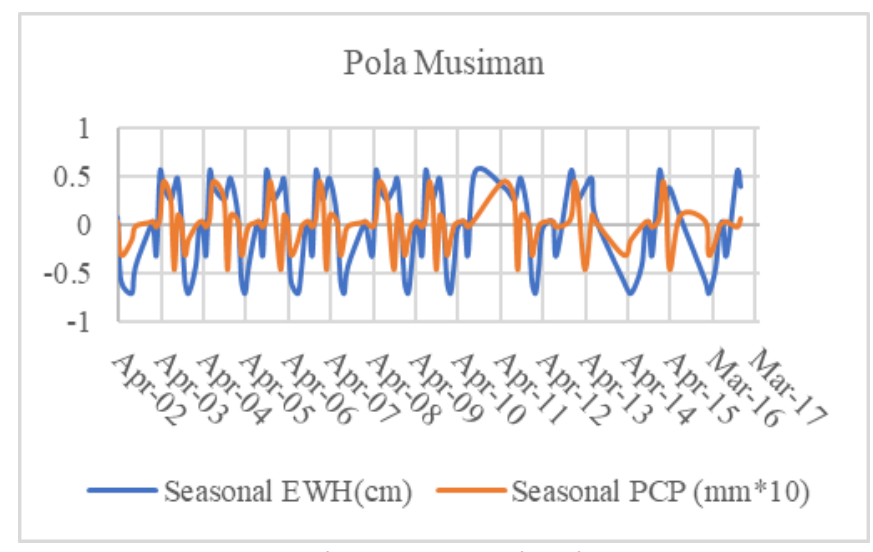

Analisis musim wilayah 4

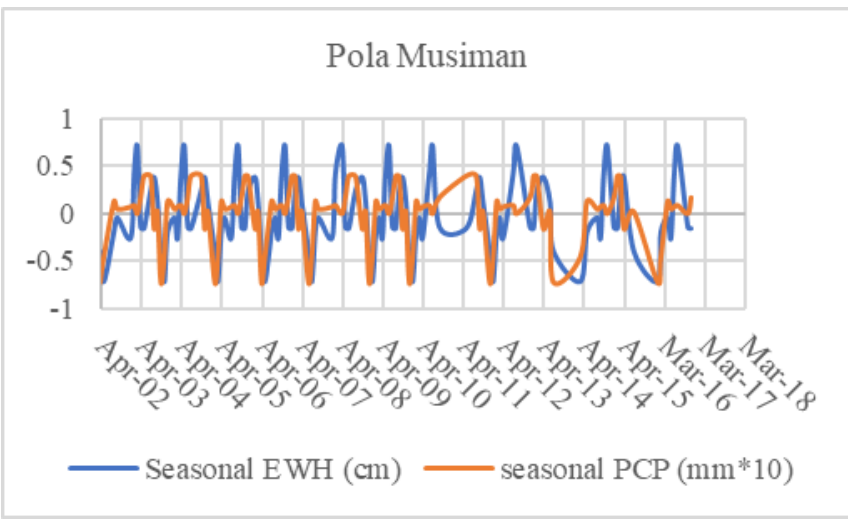

Analisis musim wilayah 6

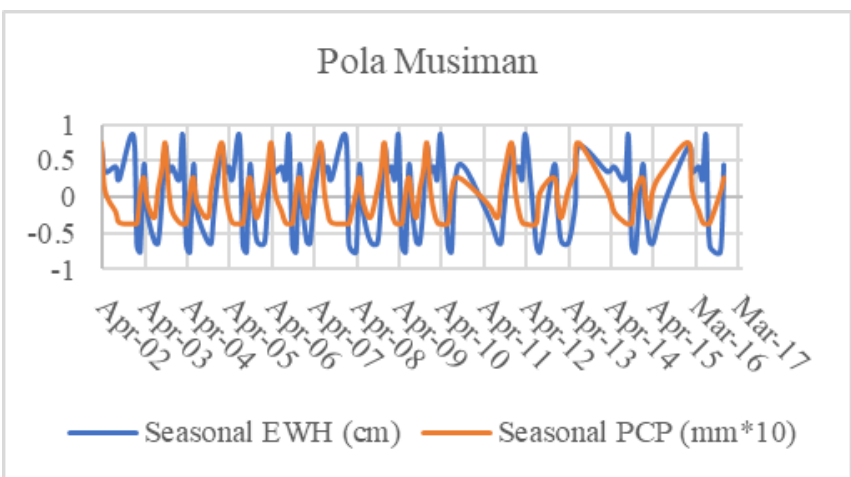

Analisis musim wilayah 8

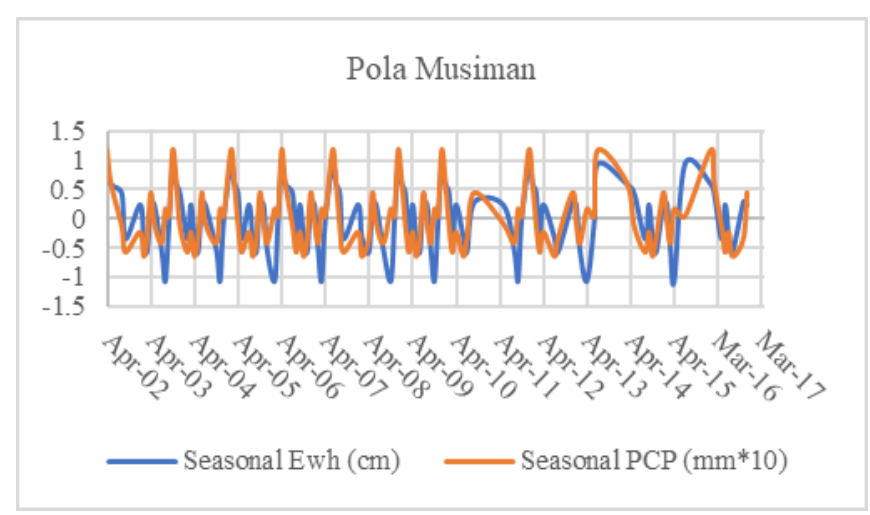

Analisis musim wilayah 9 


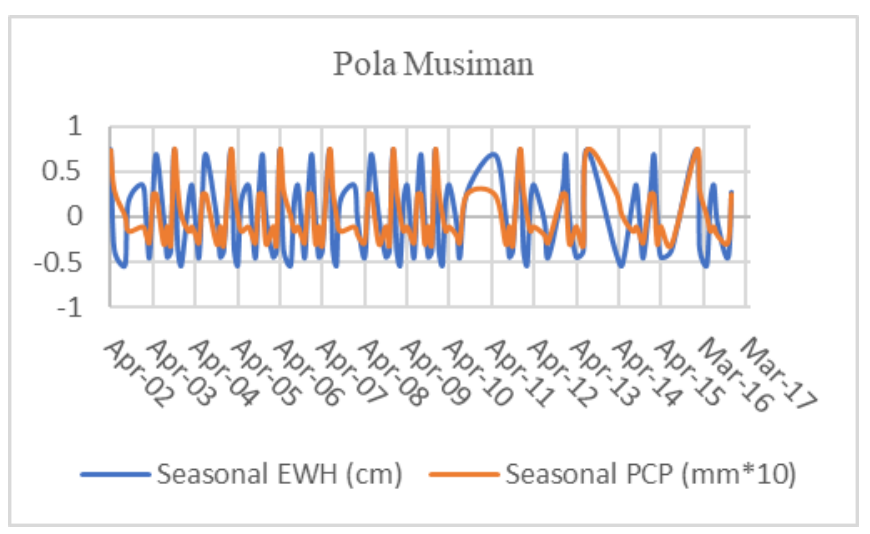

Analisis musim wilayah 10

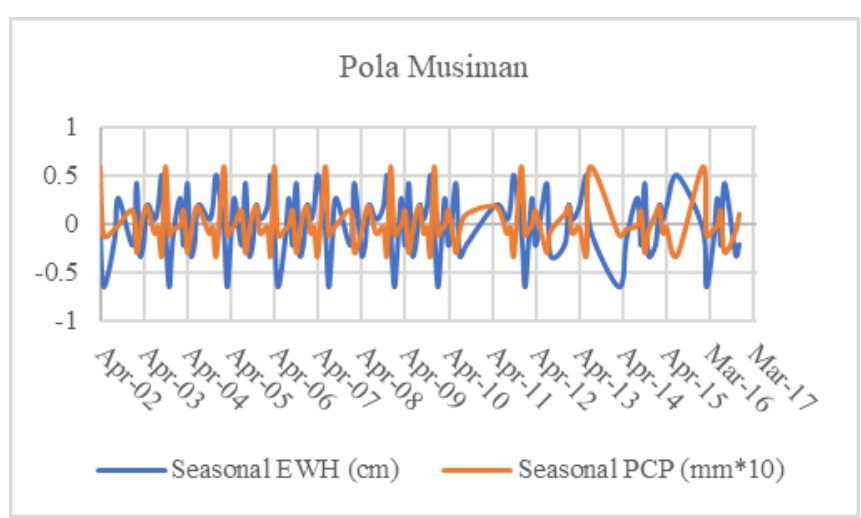

Analisis musim wilayah 11
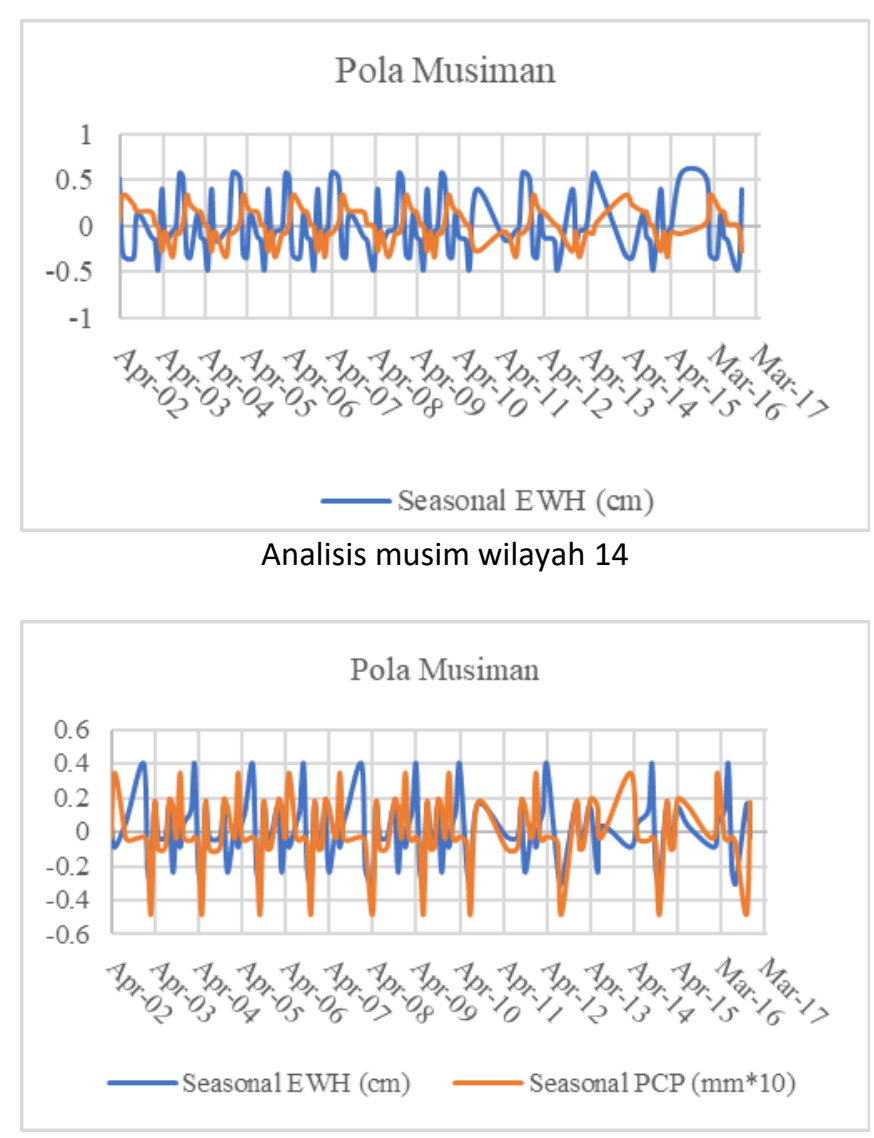

Analisis musim wilayah 15 